\title{
Characterization of Rome's rainwater in the early of 2018 aiming to find correlations between chemical-physical parameters and sources of pollution: a statistical study
}

\section{Luca Ugo Fontanella, et al. [full author details at the end of the article]}

Received: 18 September 2019 / Accepted: 29 September 2020/

Published online: 26 November 2020

(C) The Author(s) 2020

\begin{abstract}
Analysis of rainwater in historical cities plays a key role to save ancient monuments from atmospheric agents. In this study we sampled the Rome's rainwater from February to July of 2018 and we analysed them to determine their chemical and physical parameters: $\mathrm{pH}$, redox potential, conductivity, temperature, and the concentration of the main inorganic ions $\left(\mathrm{Na}^{+}, \mathrm{K}^{+}, \mathrm{Ca}^{++}, \mathrm{Mg}^{++}, \mathrm{F}^{-}, \mathrm{Cl}^{-}, \mathrm{NO}_{3}^{-}\right.$, $\mathrm{SO}_{4}^{--}$). The volume of the daily fallen rainwater, the speed and direction of the wind in the sampling site were also collected. In order to find a correlation between all the above data we used the Principal Component Analysis (PCA). Results evidenced that there aren't authentic "acid rains" as the minimum $\mathrm{pH}$ value that we found is 5.2. In some cases high concentrations of nitrates and sulphates were found with maximum values of $12.4 \mathrm{ppm}$ and $18.7 \mathrm{ppm}$ respectively. We also found no correlation between the rainwater's composition and the seasonal period; on the contrary, the speed and direction of the wind, especially when coming from the sea or industrial country near Rome, play a noticeable role on the rainwater composition.
\end{abstract}

Keywords Italy Rome's rainwater · Monitoring of chemical-physical parameters · Inorganic ions · Acid rain $\cdot$ Chemometrics . Pollution sources

\footnotetext{
- The chemical composition $\left(\mathrm{Na}^{+}, \mathrm{K}^{+}, \mathrm{Ca}^{++}, \mathrm{Mg}^{++}, \mathrm{F}^{-}, \mathrm{Cl}^{-}, \mathrm{NO}_{3}^{-}, \mathrm{SO}_{4}^{-}, \mathrm{pH}\right.$, redox potential (ORP), conductivity), and some physical parameters (temperature, daily volume, wind speed and direction) were monitored for rainwater fell in Rome, Italy in the early of year 2018 as.

- A correlation between the above parameters was looked for using the Principal Component Analysis (PCA).

- PH resulted no too acidic even if in case of the highest concentration of nitrates and sulphates

- Pollution was mainly correlated to the wind direction.

Capsules:

Scarce and dated literature is available on quality of Rome's rainfall

Our statistical data treatment highlighted no acidic rainwater probably due to neutralization of acidic gases by limestone particulate transported by wind

Ionic composition does not involve seasonal variations that are instead bound to physical parameters Further data on a wider time range, in different urban and nearby hinterland Rome sampling points and with further parameters are foreseen for the research deepening
} 


\section{Introduction}

Researches on rainfall and on its chemical composition considerably increased following the discovery of the effects of acid rain over vegetation (Emberson et al. 2001), soil (Yagasaki et al. 2001), watercourses (Aggarwal et al. 2001) and buildings of historical or archaeological interest (Kanazu et al. 2001). Furthermore, data on rainwater composition are useful for the validation of global transport models of chemical species present in the atmosphere and to determine the global cycle of sulphur compounds, oxidized and reduced nitrogen compounds and the transport of dust by wind (Yun-Ya and Gurpal 2017; Cuoco et al. 2013). The evaluation of the origin of the chemical constituents dissolved in rainwater can be laborious, because the composition of rainwater is the result of complex interactions between the water vapour of the clouds, other atmospheric gases, the dust raised by the wind (Rodhe et al. 1995; Langner et al. 1992). The chemical ions composition of precipitation, however, can be correlated to local sources of pollution in urban areas (Conlan et al. 1995), but also to relatively distant sources, if there is a phenomenon of atmospheric transport (Sanusi et al. 1996; Satyanarayana et al. 2010). The $\mathrm{pH}$ of precipitation depends essentially on the result of neutralization reactions between the acidic components of rainwater, mainly derived from gases such as carbon dioxide, nitrogen oxides and sulphur oxides (Mouli et al. 2005) and the basic components, especially $\mathrm{NH}_{3}$, bicarbonates, carbonates and hydroxides of calcium and magnesium (Masaki et al. 2002) (mainly becoming from erosion phenomena), which penetrate inside the rain droplets (Monika et al. 2000). Rain droplets also incorporate, and transport over the city, micropollutants as polycyclic aromatic hydrocarbons (PAHs), phthalate ester (PEs), pesticides, polychrorinated biphenyls (PCBs), thus contributing the local pollution (Guidotti et al. 2000). The presence of heavy metals in the rains seems to be mainly linked to the use of fossil fuels (especially the combustion of coal), which release unburned micro-particles containing metal ions, which are solubilized in the water from the clouds (Migon et al. 1997; Singh et al. 2007). For these problems, the monitoring of the chemical composition of rain in Rome is very important, in particular for the large number of monuments and archaeological finds exposed to the rains present in this city (Camuffo 1992); despite the importance of the subject for a city with the bigger concentration of Cultural Artifact in Italy, there are no recent published studies. In the References section we can find an article on the ratio ${ }^{134} \mathrm{Cs} /{ }^{137} \mathrm{Cs}$ measured in rain that fell on Rome, dated 1971 (Cigna et al. 1971). An other study treats with sulphate content in rain fell in the urban area of Rome and is dated 1988 (D'Innocenzio and Ottaviani 1988). The most recent paper on Rome's rainwater dates 14 years ago; the content of the same above cited ions and of heavy metals, coming from the sampling of PM10 on teflon filter, were determined (Canepari et al. 2006). On these bases, the research here exposed seeks to fill this gap, at least in part; at this aim chemical and physical parameters $\left(\mathrm{Na}^{+}\right.$, $\mathrm{K}^{+}, \mathrm{Ca}^{++}, \mathrm{Mg}^{++}, \mathrm{F}^{-}, \mathrm{Cl}^{-}, \mathrm{NO}_{3}^{-}, \mathrm{SO}_{4}^{--}, \mathrm{pH}, \mathrm{ORP}$, conductivity, temperature, volume of the rainwater were monitored by daily samplings of rainwater in the period FebruaryJuly 2018. The geographical position and the nature of the sources (natural or anthropogenic) letting to the characteristics of the fallen water were obtained basing on the direction and speed of the wind over the sampling site. A chemometric data treatment by Principal Component Analysis (PCA), was used to find a correlation between all the collected data. 


\section{Methods}

\subsection{Sampling}

The rain was collected on the roof of the "Cannizzaro" institute of the chemistry department of "La Sapienza" University of Rome, Italy (GPS coordinates: 41 54 ' 07" $\mathrm{N} 12^{\circ} 30^{\prime} 50^{\prime \prime} \mathrm{E}, 69.5 \mathrm{~m}$ asl). The sampling site is located in a central area of Rome, an urban area of almost $1300 \mathrm{~km}^{2}$ inhabited by about 2.8 million people and, although it lacks significant industrial facilities, it is characterized by intense urban traffic and emissions from thermal power stations of public and private buildings (see Fig. A in Electronic Supplementary Material, (ESM)). The climate of Rome is Mediterranean with a relative humidity between $60 \%$ and $80 \%$, with significant temperature variations between the different seasons: winter (12.8 max. and $2.8 \mathrm{~min}$.), spring (19.8 max. and $7.3 \mathrm{~min}$.), summer (30.4 max. and $16.2 \mathrm{~min}$.) and autumn (22.1 max. and $10.2 \mathrm{~min}$.); annual rainfall is about $800 \mathrm{~mm}$ of rain (Fabrizi et al. 2010). The area around Rome is characterized by minor inhabited urbane centres and agricultural areas, fairly more abundant at south of the city, as well as wooded areas, more abundant in the north and east areas; about $30 \mathrm{~km}$ to the west and south-west of the sampling site there is the Tyrrhenian Sea, to the east there is the Apennine mountain range, consisting essentially of calcareous rocks (Ciarapica and Passeri 1998). The nearest industrial centre with a heavy environmental impact is the city of Terni, located about $100 \mathrm{~km}$ to the north-east; furthermore, there are some small industries specialized in the pharmaceutical, food, etc. about $75 \mathrm{~km}$ south-east.

\subsection{Methods of sampling and analysis}

We collected 62 rain samples between February and July 2018, using a Pyrex beaker $(0.15$ $\mathrm{m} \emptyset$ ) placed in a point of the roof exposed to the north, to avoid direct sunlight; withdrawals always took place in the morning, replacing the beaker with one washed three times with Milli-Q water (Wu et al. 2016). The sampled rain was poured into one or more $50 \mathrm{~mL}$ polypropylene Falcon test tubes and labeled with the data; a part of the rain was used for immediate analysis directly inside the tube, the remaining for the ion chromatography (IC). The first analyses were performed with Vernier electrodes and concerned, the $\mathrm{pH}$, the conductivity and the redox potential. The other samples were stored at $4{ }^{\circ} \mathrm{C}$ (APAT 2004) until the chromatographic analysis. Simultaneously with the withdrawals, data was also collected on the wind speed and direction, from the Piazza Galeria weather station (GPS coordinates $41^{\circ} 52^{\prime} 27^{\prime \prime} \mathrm{N}, 12^{\circ} 30^{\prime} 23^{\prime}$ E, $48 \mathrm{~m}$ asl), located at about $4 \mathrm{~km}$ from the rain sampling point, while from the weather station, located in via Mozambano 10, on the roof of the Civil Engineering headquarters, about 500 meters from the rain sampling point, (GPS coordinates $41^{\circ} 54^{\prime} 14^{\prime \prime} \mathrm{N}, 12^{\circ} 30^{\prime} 26^{\prime \prime} \mathrm{E}, 84 \mathrm{~m}$ asl) we collected data on the rainfall volume, atmospheric pressure and temperature.

\section{Materials}

The Vernier (Beaverton, Or, USA) electrodes were used for $\mathrm{pH}$ (PH-BTA), for redox potential (ORP-BTA) and for conductivity (CON-BTA) measurements. 
For cations we used a chromatograph 761 compact IC Metrohm (Herisau, $\mathrm{CH}$ ) with Dionex column (Sunnyvale, Cal, USA) CS12A 4x250 mm, using inline Supelco filter (Sigma, USA) $2 \mu \mathrm{m}$ as precolumn and software interface IC NET 2.3; eluent: $2 \mathrm{mM}$ aqueous nitric acid solution Carlo Erba (Milan, IT), 4 mM anhydrous oxalic acid Carlo Erba, 1\% V/V acetonitrile from MS Fluka (Milan, IT) have been used, all ultrapure laboratory grade.

For anions we used an other chromatograph 761 compact IC Metrohm with Dionex column AS14A 4x250 mm, using Rheodyne inline filter filter (Sigma-Aldrich) $1 \mu \mathrm{m}$ as precolumn, Metrohm ion suppressor Suppressor Module and IC NET 2.3 software interface; eluent: $2.3 \mathrm{mM}$ anhydrous sodium carbonate solution Merck Certipur (Darmsdat, DE) 99.9\%, $2.2 \mathrm{mM}$ anhydrous sodium bicarbonate 99.5\% Fluka (Milan, IT), 1\% v/v SigmaAldrich methanol (Saint Louis, Missouri, USA) 99.8\%, all ultrapure laboratory grade were employed.

The Vernier electrodes were calibrated using XS Instruments Greenline calibration solutions (Carpi, IT)

Sigma-Aldrich TraceCert standard solution for AAS (Saint Louis, Missouri, USA) were used for the calibration of cations ion chromatographs of lithium, sodium, potassium, ammonium, magnesium, calcium and strontium; Merck Certipur anion multi-element standard was used for fluoride, phosphate, bromide, chloride, nitrate, sulphate, oxalate and acetate (Darmsdat, DE).

\section{Results and discussion}

All the data and the results of the analyses carried out in this research are summarized in Table 1; in particular for each rain's day, reported in the first column, it can be read: the volume of rainfall as mm of rain $\left(1 \mathrm{~mm}\right.$ of rain $\left.=1 \mathrm{~L} / \mathrm{m}^{2}\right)$, the atmospheric pressure, the rain temperature and how many days elapsed since the previous rain day (just as examples, 1 means that rain also occurred on the previous day and 2 which did not rain the previous day but the one before the previous one), $\mathrm{pH}$, conductivity, redox potential, the cation (sodium, potassium, ammonium, magnesium and calcium) and anion (fluoride, chloride, nitrate and sulphate) contents. An extended scoreboard of the data collected is also presented in Fig. B of the ESM while the Scatterplot Matrix and the SPLOM, with all correlation charts are shown in Fig. C of the ESM. Some general observations can be made by reading Table 1: first, the rain fell in Rome in a very discontinuous way (Fig. 1), while the fallen volume was in most of the cases between 20 and 0.5 $\mathrm{L} / \mathrm{m}^{2}$ (uncertainty $0.1 \mathrm{~L} / \mathrm{m}^{2}$ ), the rain $\mathrm{pH}$ was always higher than 5 (uncertainty $0.1 \mathrm{pH}$ units), (Fig. 2) consequently no authentic acid rains were recorded (Calvert 1990). Finally, the redox potential of the samples was rather stable, around $350 \mathrm{mV}(1 \mathrm{mV}$ uncertainty), while the conductivity varied considerably (from 20 to $120 \mu \mathrm{S}$, with an uncertainty of $1 \mu \mathrm{S}$ ). In IC each rain sample was analyzed at least three times, the quantification limit for anions is $0.2 \mathrm{mg} / \mathrm{L}$,

Table 1. seasonal average of the measured parameters, LOQ = Limit Of Quantification

\begin{tabular}{llllllllllll}
\hline Season & $\begin{array}{l}\text { pluvio } \\
\mathrm{mm}\end{array}$ & $\begin{array}{l}\text { acidity } \\
\mathrm{pH}\end{array}$ & $\begin{array}{l}\mathrm{ORP} \\
\mathrm{mV}\end{array}$ & $\begin{array}{l}\text { conduct. } \\
\mu \mathrm{S}\end{array}$ & $\begin{array}{l}\mathrm{Na}+ \\
\mathrm{ppm}\end{array}$ & $\begin{array}{l}\mathrm{K}+ \\
\mathrm{ppm}\end{array}$ & $\begin{array}{l}\mathrm{Mg}+ \\
\mathrm{Ppm}\end{array}$ & $\begin{array}{l}\mathrm{Ca}++ \\
\mathrm{ppm}\end{array}$ & $\begin{array}{l}\mathrm{Cl}- \\
\mathrm{ppm}\end{array}$ & $\begin{array}{l}\mathrm{NO3}- \\
\mathrm{ppm}\end{array}$ & $\begin{array}{l}\mathrm{SO} 4 \\
\mathrm{ppm}\end{array}$ \\
\hline Winter & 7.5 & 6.21 & 347 & 42.5 & 2.5 & 1.6 & 1.3 & 8.0 & 3.5 & 2.9 & 4.0 \\
Spring & 9.3 & 6.57 & 344 & 48.5 & 4.0 & 2.6 & 2.7 & 7.6 & 5.4 & 3.3 & 4.1 \\
summer & 8.2 & 6.63 & 342 & 29.1 & 2.5 & 1.2 & $<\mathrm{LOQ}$ & 2.8 & 2.8 & 2.5 & 2.3 \\
\hline
\end{tabular}




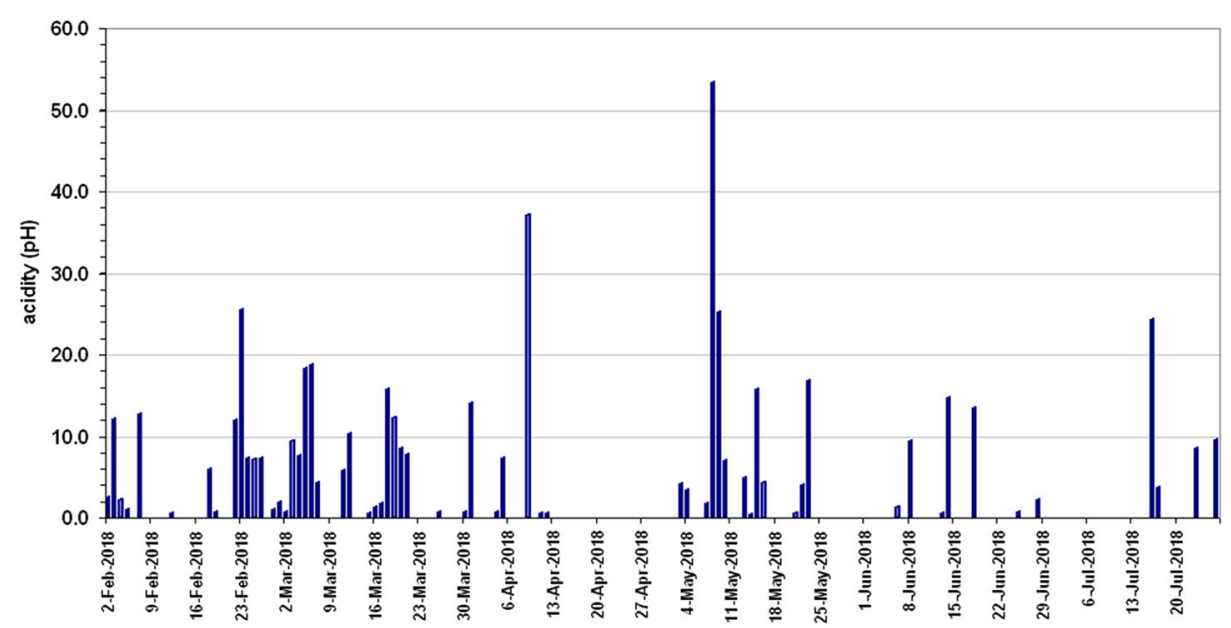

Fig. 1 Rainfall (mm) that fell over Rome during the sampling period

while for cations it is $1 \mathrm{mg} / \mathrm{L}$, the accuracy of the measurement, calculated as standard deviation resulted about $5 \%$ for cations and $2 \%$ for anions. The result of the chromatographic analysis showed that: the total content (expressed in milli-equivalents / $\mathrm{L}$ ) of the main cations $\left(\mathrm{Na}^{+}, \mathrm{K}{ }^{+}, \mathrm{NH}_{4}{ }^{+}, \mathrm{Ca}^{++}\right.$and $\left.\mathrm{Mg}{ }^{++}\right)$and that of the main anions $\left(\mathrm{F}^{-}, \mathrm{Cl}^{-}, \mathrm{NO}_{3}^{-}, \mathrm{SO}_{4}^{--}\right)$, as expected, fit a sufficiently linear trend (Figs. 3 and 4); the total ions content (anions and cations) of the daily sampled rain shows instead an exponential decrease as function of the daily volume of rainfall $\left(\mathrm{L} / \mathrm{m}^{2}\right)$. This trend is probably related to the air washing effect caused by rain. In fact, the first drops of rain pass through the dirtier air which, in turn, gradually becomes cleaner; the only effect of the further increase in volume is therefore the dilution. The high variability of the ion content at low volume values, anyway bound to the "cleaning" effect, can be explained both with different direction and strength of wind and/or abundant precipitation in the previous days that strongly reduced the concentrations of gas and dust in the area (Herut et al. 2000; Orué et al.

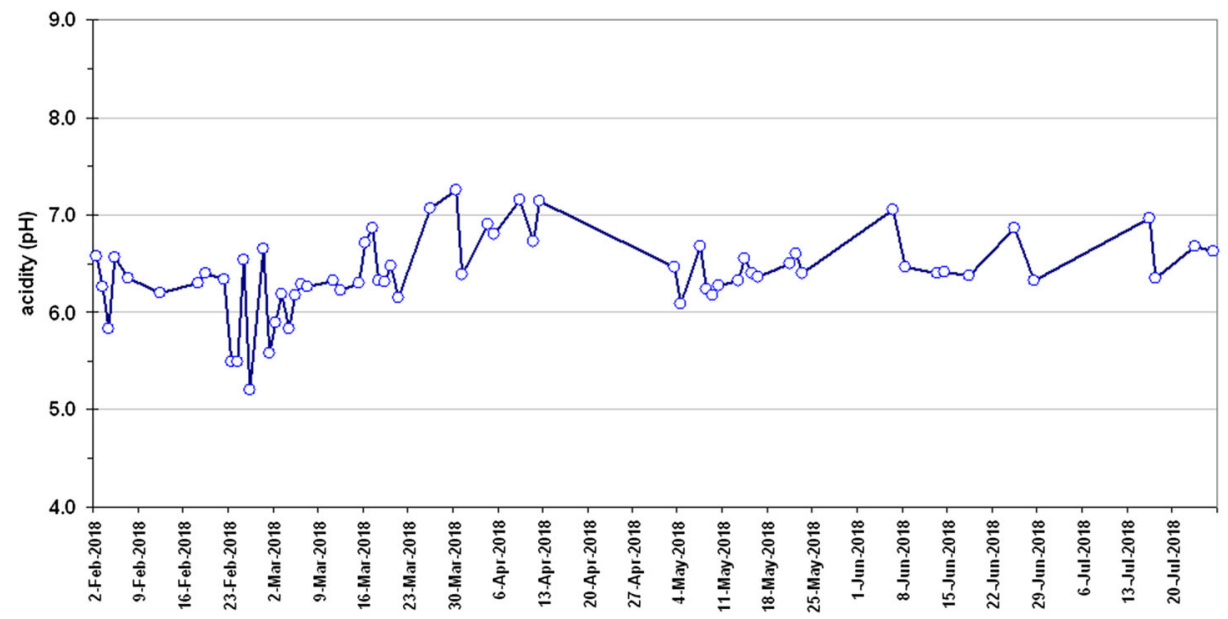

Fig. $2 \mathrm{pH}$ of Rome's rainwater in the sampling period 


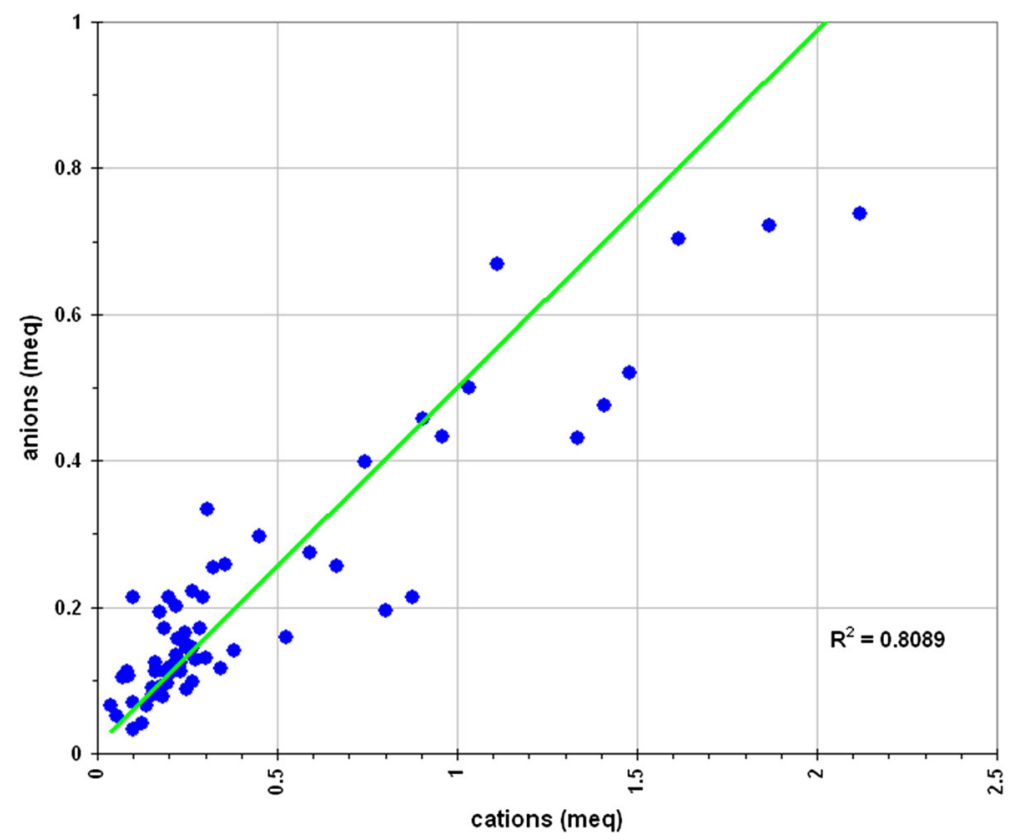

Fig. 3 Correlation between anions and cations (meq) obtained for Rome's rainfall during the sampling period

2019). This "cleaning" effect does not seem to be very significant in general, looking to our results except in a particular case that will be described later. An excellent correlation was found between the sum of the concentrations of sodium and potassium ions and that of chloride ion.

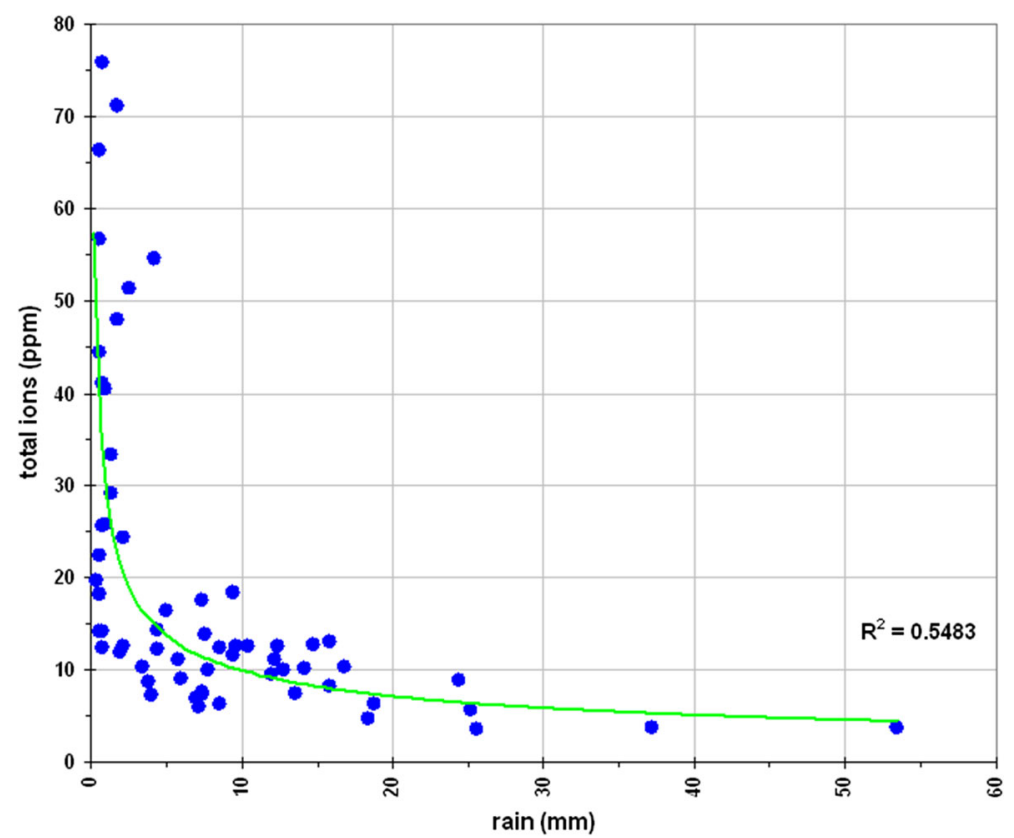

Fig. 4 Correlation between the total salts content (ppm) and rainfall (mm)

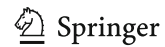




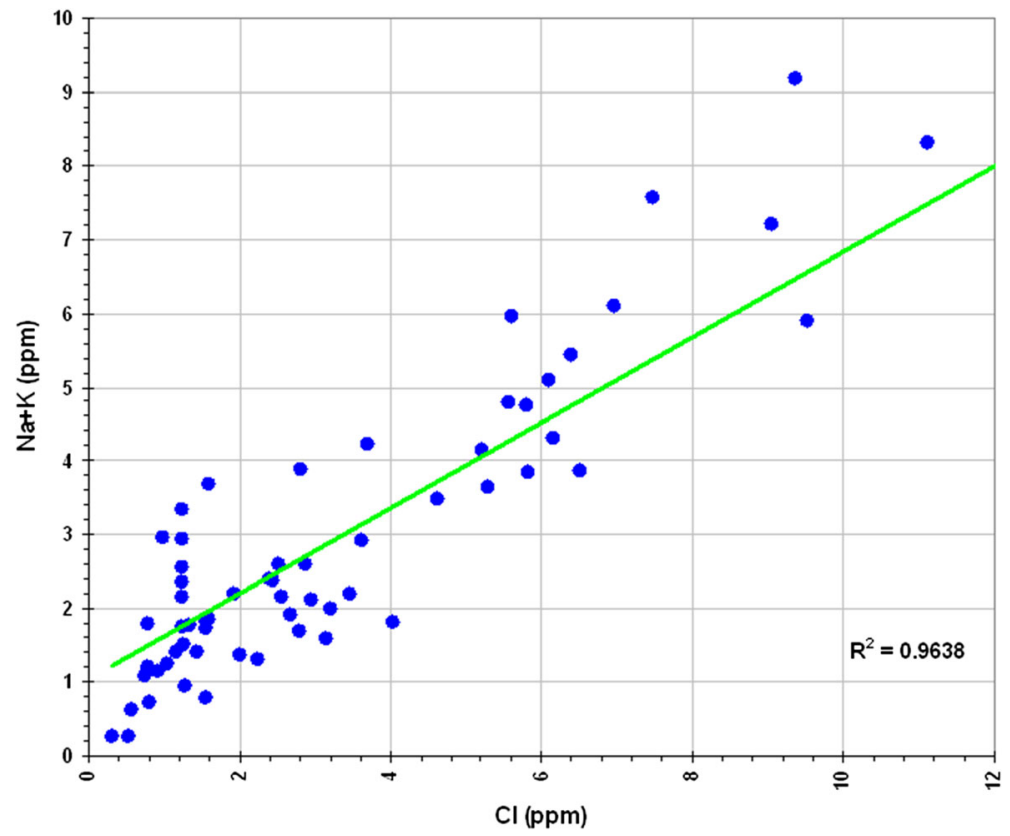

Fig. 5 Correlation between the sum of $\mathrm{Na}^{+}$and $\mathrm{K}^{+}$contents (ppm) and $\mathrm{Cl}^{-}$content (ppm)

This suggests that these ions come mainly from sea water (Fig. 5) (Jarada et al. 1999). The correlation between the sum of the concentrations of calcium and magnesium ions and that of

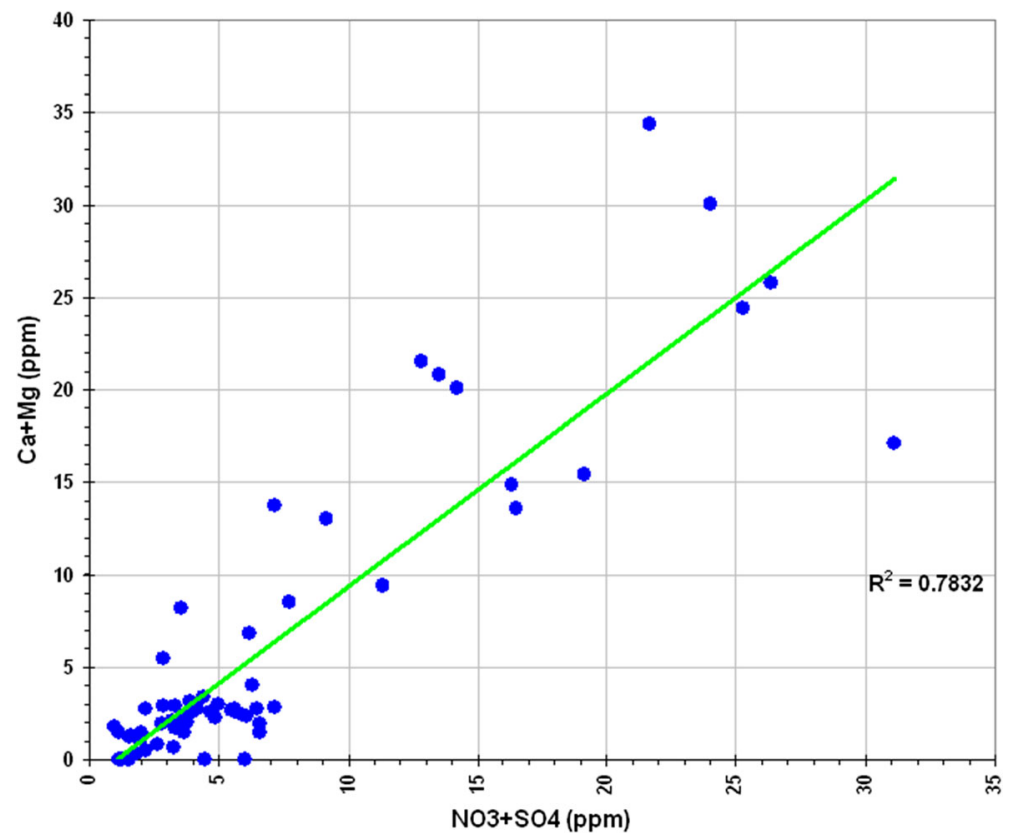

Fig. 6 Correlation between the sum of $\mathrm{Ca}^{++}$and $\mathrm{Mg}^{++}$contents (ppm) and the sum of $\mathrm{NO}_{3}{ }^{-}$and $\mathrm{SO}_{4}{ }^{--}$contents (ppm) 


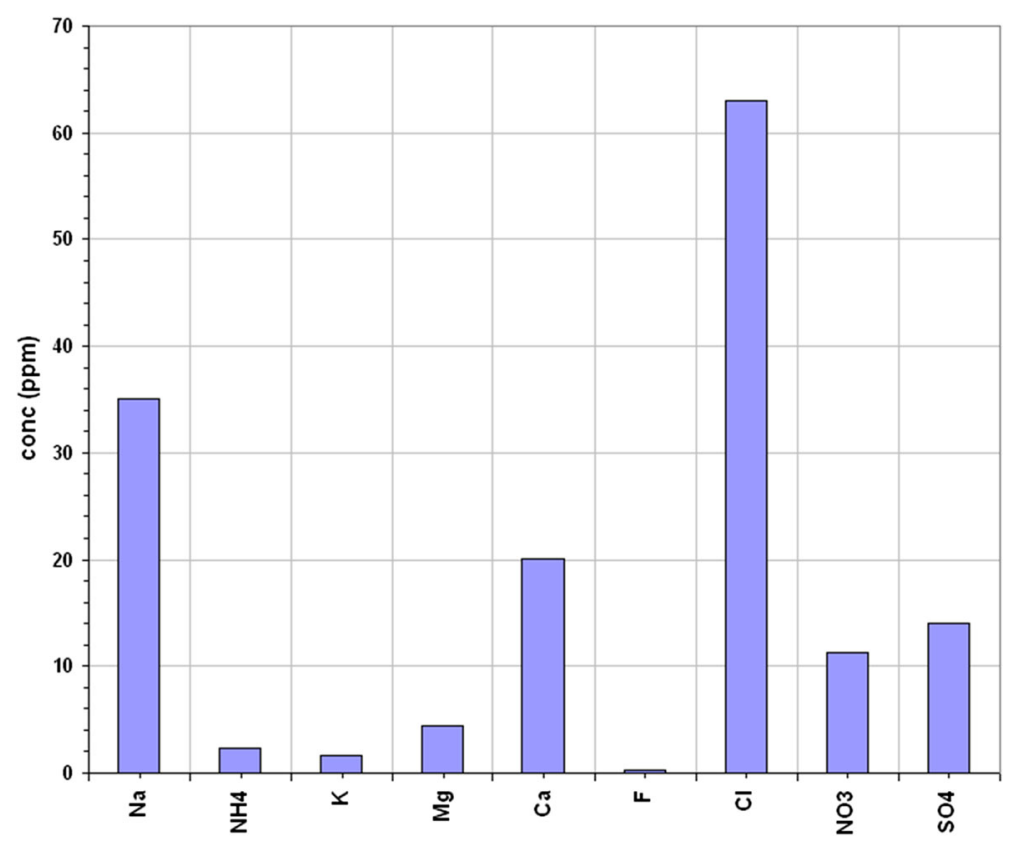

Fig. 7 Ionic composition of the Rome's rainwater sampled on 4 April 2018

the nitrate and sulphate ions (Fig. 6) could be imputed to the neutralization of nitric and sulphuric acids (coming from the nitrogen and sulphur oxides of anthropogenic origin), through reaction with only calcium and magnesium carbonates contained in the dust deriving from wind erosion (Huang et al. 2009). The correlation between cations and anions is also shown in Fig. D in the ESM using other widely used charts. To confirm the above hypotheses on the source and provenance of the ions contained in the analysed rain, we selected three samples corresponding to three days where these effects was accentuated, i.e. days characterized by a scarce rain that fell after several days of no rained; in such samples a significantly higher ions content was found. As already said, data on the speed and direction of the wind that blew over the area were collected also for the two days prior to sampling (more detailed graphs are shown in Fig. E ESM). Using a sampling time of $24 \mathrm{~h}$ for the rain, the wind direction of the one or two previous days is interesting but also the wind in the day of sampling itself must be evaluated. Results show, for example, a high concentration of sodium ions and chloride ions in the rain sample collected on April 4 (Fig. 7); data also show that in the previous two days, during which it did not rain, a strong south wind blew (with short gusts from the north-east) (Fig. 8). As already said, the sea is south of Rome (see Fig. A); so, this seems demonstrate that a phenomenon of transport of sea salt in the air above the city occurred. On the contrary, it was found that, in the rain that fell on May 21st, high concentrations of calcium, nitrates and sulphates were present (Fig. 9) and that, in the two previous days, wind blew from the north-east and southeast (Fig. 10). North-east of Rome there is a "wind corridor" between the Apennines and the anti-Apennines mountains, which crosses the city of Terni (about $100 \mathrm{~km}$ from Rome), such city always shows significant air pollution problems (Massimi et al. 2017); the same mountains continues south-east of Rome. On these bases, it is conceivable that the dusts originating from the wind erosion of these mountain, being of calcareous nature, can 


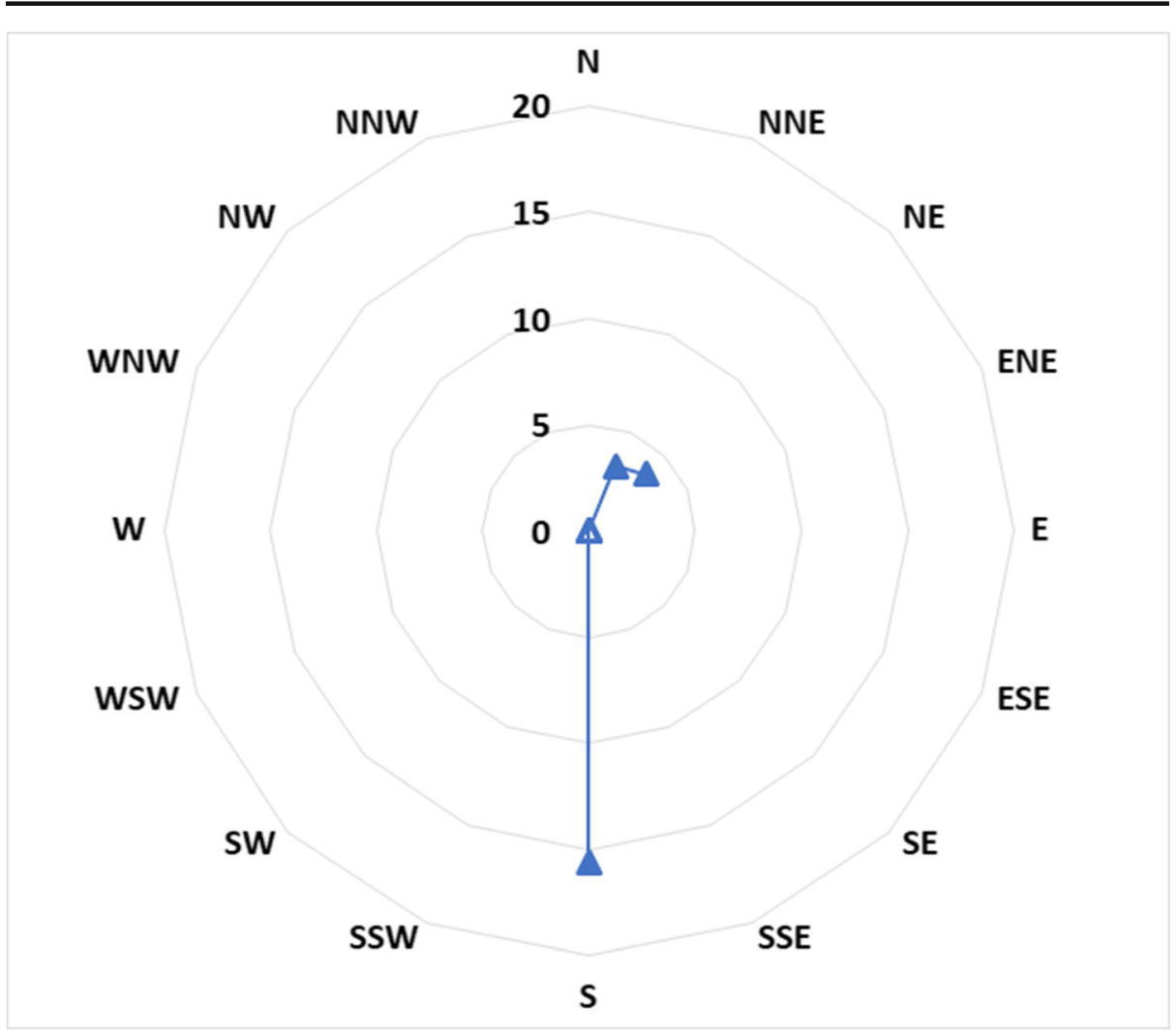

Fig. 8 Speed $(\mathrm{Km} / \mathrm{h})$ and direction of the winds that blew on the sampling site on 2 and 3 April 2018

neutralize the acidity coming from the sulphur and nitrogen oxides and, in turn, reduce the pollution of the Rome atmosphere of and, probably of the area nearby of Terni city. Finally, it was very clear how the rain of June 25 th presents low concentrations of all ions, max. $4 \mathrm{ppm}$ (Fig. 11). Although the amount of rain was low on the day of collection and that in the previous days it had not rained at all, in the two previous days a strong north-east wind had blew (Fig. 12) with small gusts from the south-east; it is conceivable that the strong wind has in this case removed the polluting gases and dust so having a cleaning effect that results in a very poor-ions rain (Báez et al. 2007). In order to highlight a correlation between the analyzed parameters and the seasonal period of the sampling (winter, spring and summer), the principal component analysis (PCA) was performed using all the collected data after an autoscaling pre-treatment. Unfortunately, the scores of the first and second PCA components, do not show any separation of the samples on a hypothesized seasonal basis (this representation was reported in the ESM as Fig. F). Anyway, analysing the loadings related to this PCA, it can be noted that data related to the ion concentration lie on a vertical line, on the extreme right of the graph (PC1 0.2-0.4), while the other chemicalphysical parameters lie instead enough separated in the four quadrants of the graph (Fig. 13). This suggested us to perform a second PCA analysis using only the parameters concerning temperature, $\mathrm{pH}$, conductivity, redox potential, atmospheric pressure, volume 


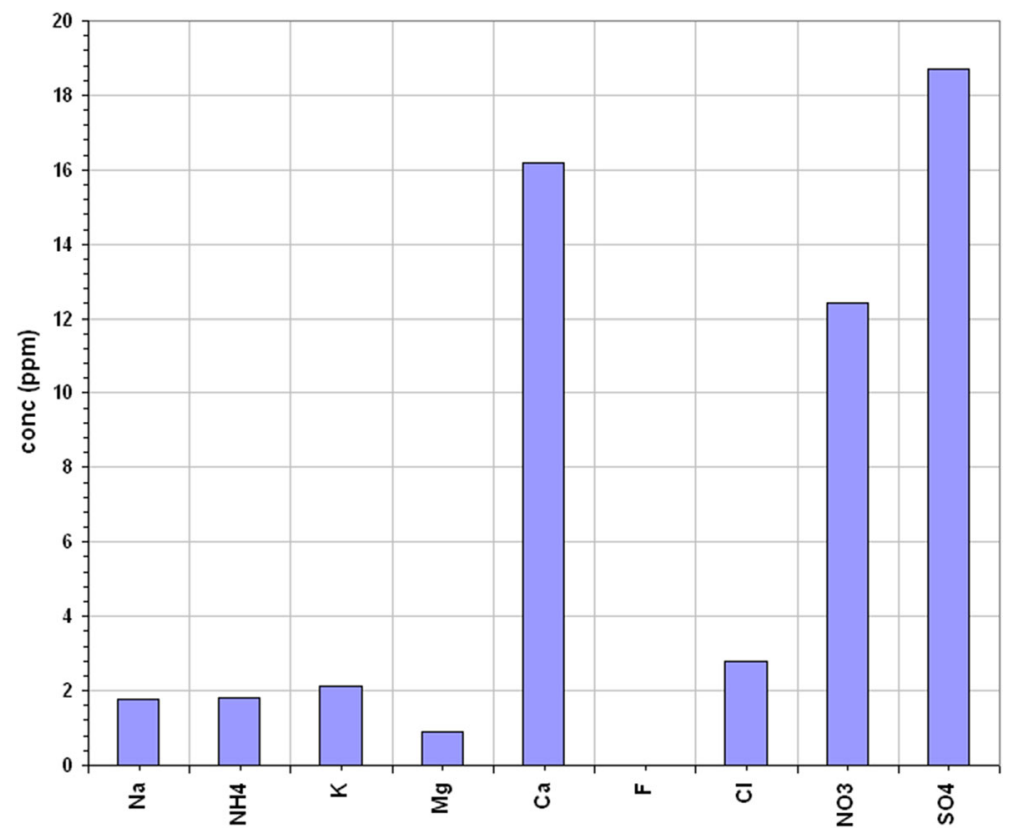

Fig. 9 Ionic composition of the Rome's rainwater sampled on 21 May 2018

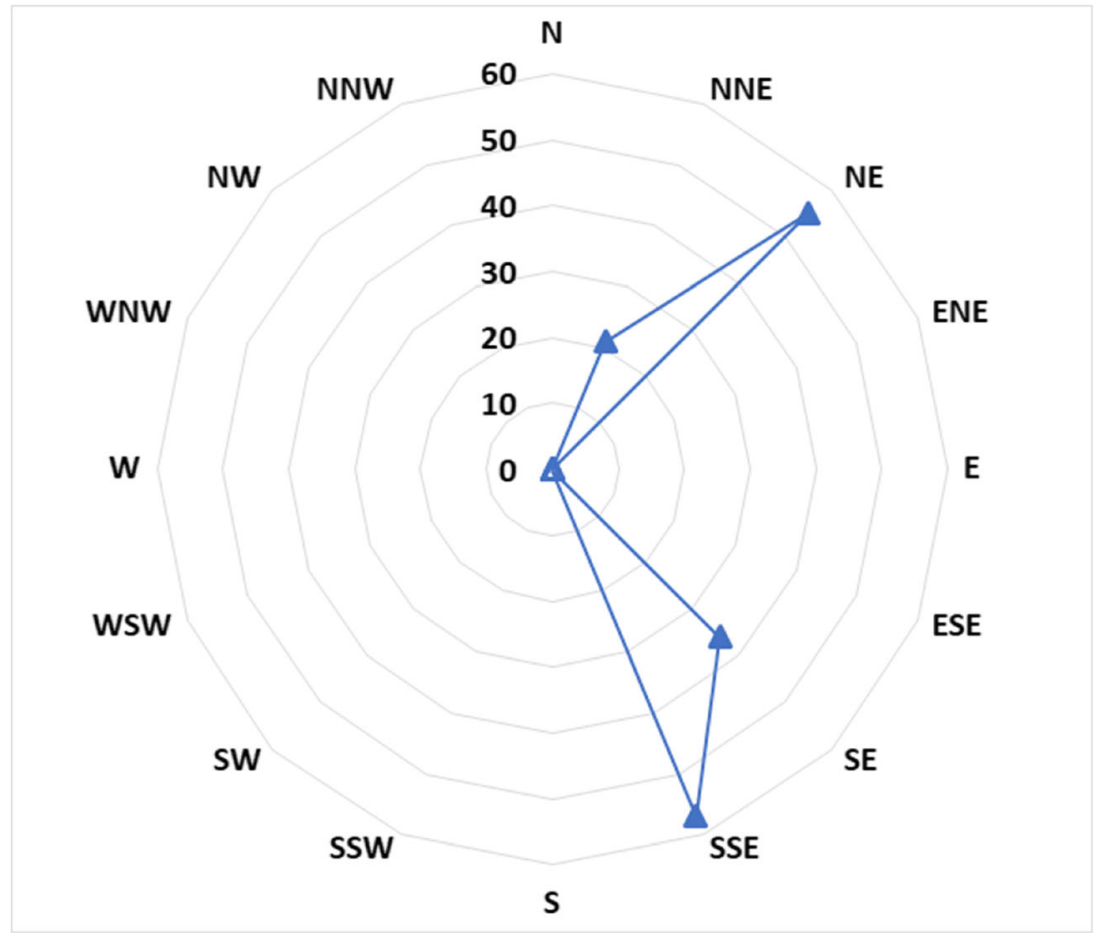

Fig. 10 Speed $(\mathrm{Km} / \mathrm{h})$ and direction of the winds that blew on the sampling site on 19 and 20 May 2018 


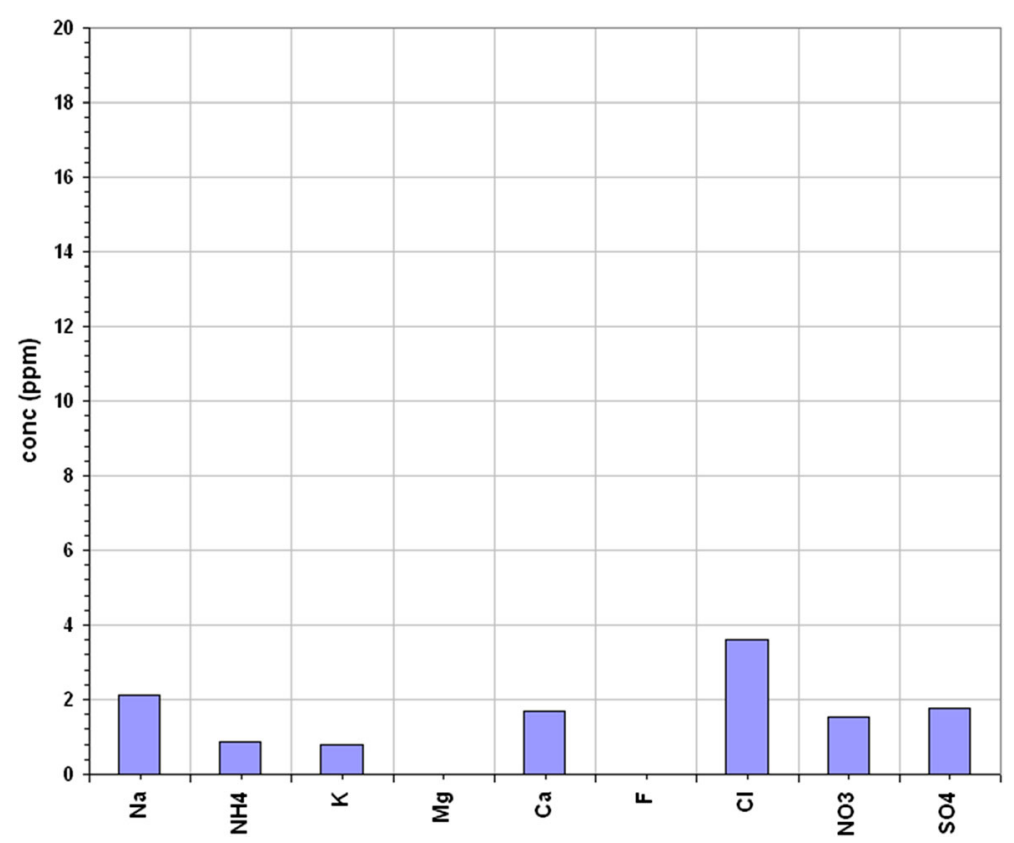

Fig. 11 Ionic composition of the Rome's rainwater sampled on 25 June 2018

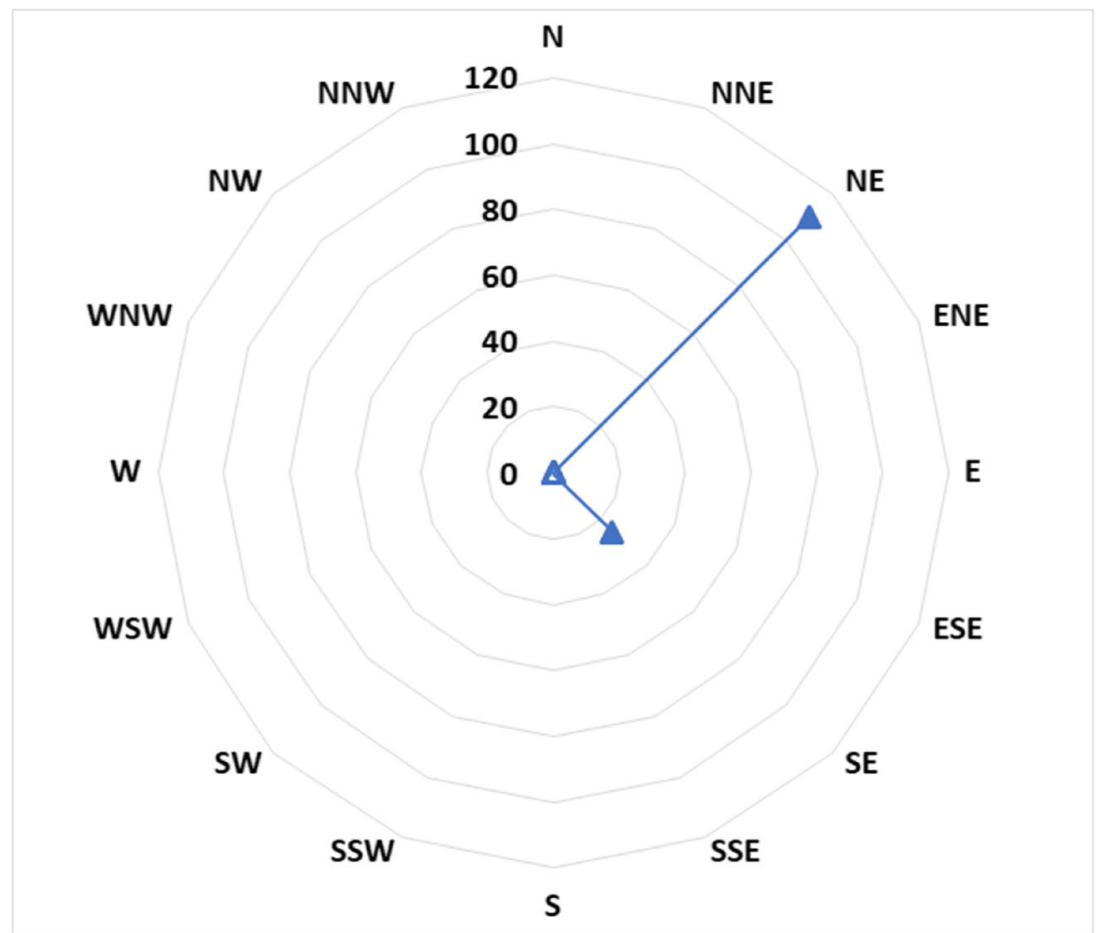

Fig. 12 Speed $(\mathrm{Km} / \mathrm{h})$ and direction of the winds that blew on the sampling site on 23 and 24 June 2018 


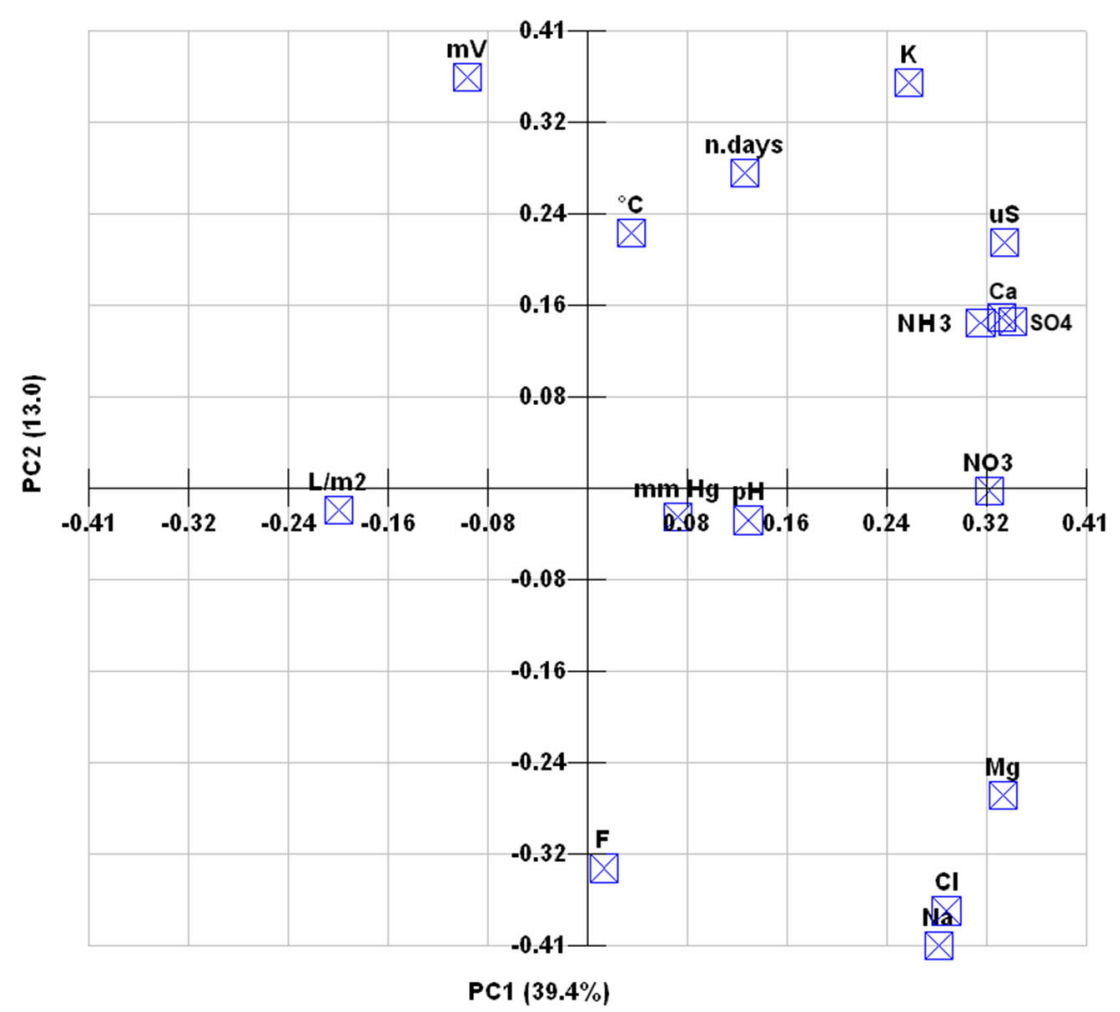

Fig. 13 Loading of the 2 first PCA components using all collected data, after autoscaling, in isometric scale

of rainfall and number of days from the last precipitation; in this case the representation of the scores, shown in a three-dimensional diagram (Fig. 14) showed a discrete separation of the data, based on the three seasons in which the sampling was carried out (the $3 \mathrm{D}$ chart of loadings was reported in the ESM as Fig. G). This successful separation of rainy days according to the three seasons, by excluding measured ionic concentrations, allows us to conclude that on average the nature and concentration of the various ions contained in the rain falling on Rome is generally almost independent of seasonal variation; this result agrees with a similar research performed in Singapore on 2001 (Balasubramanian et al. 2001) (see table. A in ESM).

\section{Conclusions}

This research does not highlight serious problems related to the acidity of Rome's rains; on the contrary, in any case a discreet content of nitrate and sulphate has been found which can create problems for the numerous monuments and outdoor stone artefacts present in Rome. The ionic composition of the rain does not vary significantly between the various seasons, while considerable variations in the physical parameters have been found. The force and direction of the winds, as expected, determines a transport effect of the nitrate and sulphate ions, and therefore of air pollution, in particular from the industrial area of Terni, or of sea salt from the 


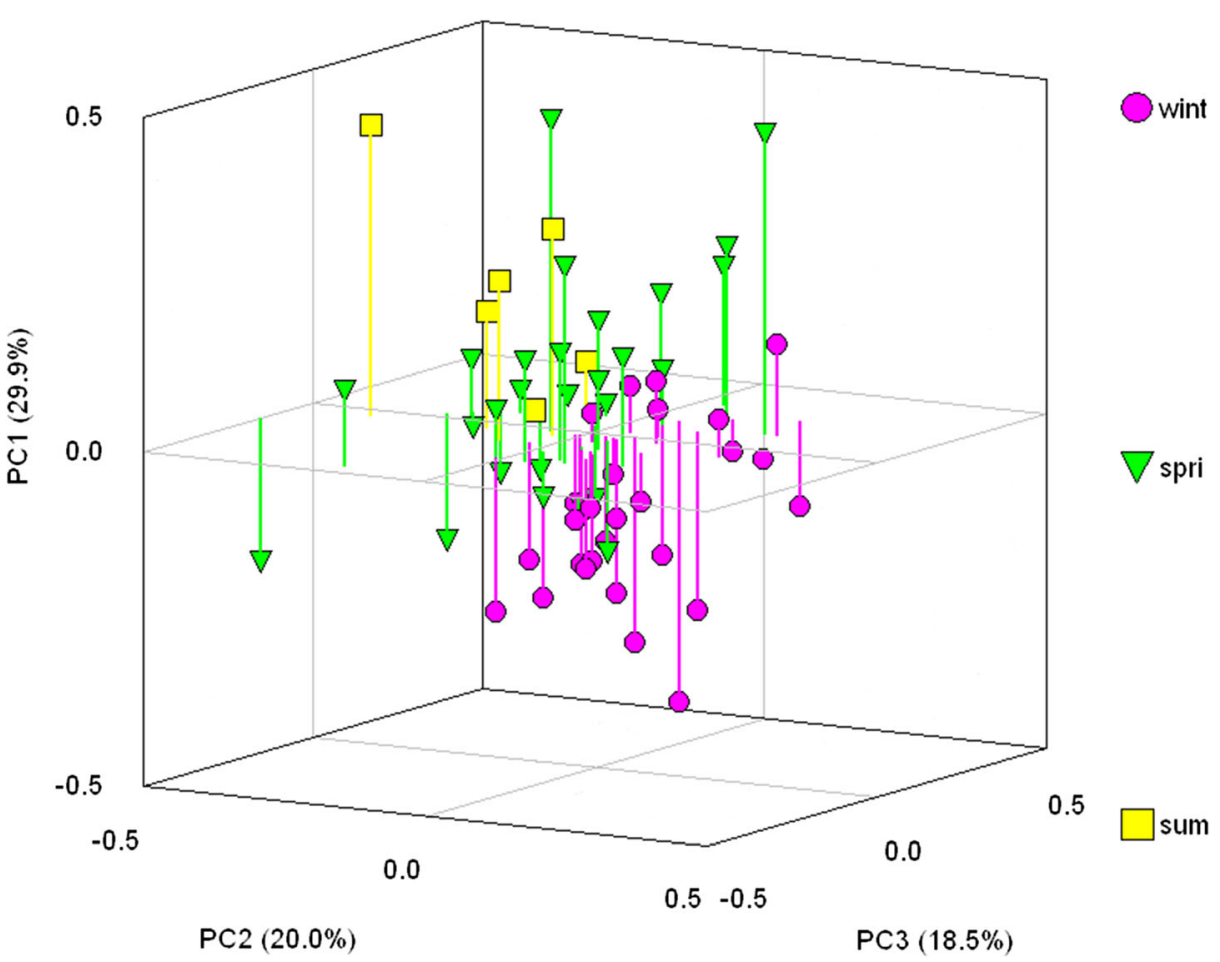

Fig. $143 \mathrm{D}$ scores chart of the main 3 PCA components, in isometric scale; only chemical-physical data were grouped by season after autoscaling pre-treatment

Tyrrhenian Sea to the south-west of Rome. Based on the experimental results, the winds also seem to transport limestone materials from the Apennine Mountains which neutralizes the acidic gas content of the atmosphere. Of course, the search must be deepened by repeating the procedure for at least a full year and as longer as possible. Other sampling points, in the city and in the nearby hinterland, could also be taken into consideration as well as other parameters such as, as examples, particulate matter, total organic and inorganic content (TOC and TIC), microplastic (already running), heavy metals.

The statistical analysis adopted for the data resulted suitable for extracting the information listed above through fairly simple views of the entire data set.

\section{Copyright}

None of the figures and data cited and used in the paper is subjected by external copyright. No third-party material was used. Authors encourage the share and reuse of data present in SOM on consider their as Open-Data. We like to thank the web site owner of www.absolutepro.co. za/applications/rain-water/ for the figure rain-water-purification-1280x854 modified by us to build the Graphical Abstract.

Supplementary Information The online version contains supplementary material available at https://oi. org/10.1007/s10874-020-09409-2. 
Funding Open access funding provided by Università degli Studi di Roma La Sapienza within the CRUICARE Agreement. Research funding comes from government budget for University, no other grant-awarding was obtained by any of the cited company. No conflict of interest occurs having not, any of authors, a financial, commercial, legal, or professional relationship with other organizations / brand / company cited in this research.

Open Access This article is licensed under a Creative Commons Attribution 4.0 International License, which permits use, sharing, adaptation, distribution and reproduction in any medium or format, as long as you give appropriate credit to the original author(s) and the source, provide a link to the Creative Commons licence, and indicate if changes were made. The images or other third party material in this article are included in the article's Creative Commons licence, unless indicated otherwise in a credit line to the material. If material is not included in the article's Creative Commons licence and your intended use is not permitted by statutory regulation or exceeds the permitted use, you will need to obtain permission directly from the copyright holder. To view a copy of this licence, visit http://creativecommons.org/licenses/by/4.0/.

\section{References}

Aggarwal, S.G., Chandrawanshi, C.K., Patel, R.M., Agarwal, S., Kamavisdar, A, Mundhara, G. L.: Acidification of surface water in Central India. Water Air Soil Pollut., 855-862 (2001). https://doi.org/10.1023 /A:1013843231487

APAT, IRSA-CNR, Metodi analitici per le acque, Manuali e Linee Guida 29/2003 [Analytical methods for water, Manuals and Guidelines], IGER Ed. Rome, isbn: 88-448-0083-7 (2004)

Báez, A., Belmont, R., García, R., Padilla, H., Torres, M.C.: Chemical composition of rainwater collected at a southwest site of Mexico City, Mexico. Atmospheric Res., 61-75 (2007) https://doi.org/10.1016/j. atmosres.2007.03.005

Balasubramanian, R., T. Victor, N. Chun.: Chemical and Statistical Analysis of Precipitation in Singapore. Water Air Soil Pollut., 451-456 (2001). https://doi.org/10.1023/A:1013801805621

Calvert, J.G.: Glossary of Atmospheric Chemistry Terms (Recommendations 1990) Paper Presented at the Annual Meeting for IUPAC, pp. 1-3. Troy, NY (1990). https://doi.org/10.1351 /pac199062112167

Camuffo D.: Acid rain and deterioration of monuments: How old is the phenomenon?. Atmospheric environment, 241-247 (1992). https://doi.org/10.1016/0957-1272(92)90027-P

Canepari, S., Cardarelli, E., Perrino, C., Catrambone, M., Pietrodangelo, A., Strincone, M.: Two-stage chemical fractionation method for the analysis of elements and non-volatile inorganic ions in PM10 samples: Application to ambient samples collected in Rome (Italy). Atmospheric Environ., 7908-7923 (2006). https://doi.org/10.1016/j.atmosenv.2006.07.005

Mouli, Chandra P, Venkata Mohan, S., Reddy, S. J.: Rainwater chemistry at a regional representative urban site: Influence of terrestrial sources on ionic composition. Atmospheric Environ., 999-1008 (2005) https://doi. org/10.1016/j.atmosenv.2004.10.036

Ciarapica, G. and Passeri, L.: Evoluzione Paleogeografica degli Appennini [Paleographic Evolution of the Apennines]" in Atti Ticinensi Scienze della Terra (7), edited by M. Vanossi, 233-290. New Press, Pavia: University of Pavia, available at https://www.socgeol.info/it/riviste?id=578, SGI code: 29985 (1998)

Cigna A.A., Clemente, G.F., Giorcelli, F.G.: On 134Cs in rainwater from 1960 to 1969. Health Phys., $667-672$ (1971). No DOI available

Conlan, D. E., S.J. Lindley and J.W.S. Longhurst: "Spatial and temporal variability in precipitation chemistry in the urban area of Greater Manchester. Water Air Soil Pollut., 2095-2100 (1995) https://doi.org/10.1007 /BF01186143

Cuoco, E., Spagnuolo, A., Balagizi, C., De Francesco, S., Tassi, F., Vaselli, O., Tedesco, D.: Impact of volcanic emissions on rainwater chemistry: The case of Mt. Nyiragongo in the Virunga volcanic region (DRC). J. Geochem. Explor., 69-79 (2013) https://doi.org/10.1016/j.gexplo.2012.11.008

D'Innocenzio, F., Ottaviani, M.: Annual monitoring of rainwater sulphate in an urban zone of Rome. Water Air Soil Pollut. 1-2, 197-202 (1988). https://doi.org/10.1007/BF00279467

Emberson, L.D., Ashmore, M.R., Murray, F., Kuylenstierna, J.C.I., Percy, K.E., Izuta, T., Zheng, Y., Shimizu, H., Sheu, B.H., Liu, C.P., Agrawal, M., Wahid, A., Abdel-Latif, N.M., van Tienhoven, M., de Bauer, L.I., Domingos, M.: Impacts of Air Pollutants on Vegetation in Developing Countries. Water Air Soil Pollut., 107-118 (2001) https://doi.org/10.1023/A:1012251503358 
Guidotti, M., Giovinazzo, R., Cedrone, O., Vitali, M.: Determination of organic micropollutants in rain water for laboratory screening of air quality in urban environment. Environ. Int. 1-2, 23-28 (2000). https://doi. org/10.1016/S0160-4120(00)00074-X

Fabrizi R., Bonafoni, S., Biondi, R.: Satellite and Ground-Based Sensors for the Urban Heat Island Analysis in the City of Rome. Remote Sens., 1400-1415 (2010) https://doi.org/10.3390/rs2051400

Herut, B., Starinsky, A., Katz, A., Rosenfeld, D.: Relationship between the acidity and chemical composition of rainwater and climatological conditions along a transition zone between large deserts and Mediterranean climate, Israel. Atmospheric Environ., 1281-1292 (2000). https://doi.org/10.1016 /S1352-2310(99)00291-5

Huang, D.Y., Xu, Y.G., Peng, P., Zhang, H.H., Lan, J.B.: Chemical composition and seasonal variation of acid deposition in Guangzhou, South China: Comparison with precipitation in other major Chinese cities. Environ. Pollut., 35-41 (2009). https://doi.org/10.1016/j.envpol.2008.08.001

Jarada, Q.M., Momani, K.A., A. G. Jiries, A. El-Alali, Batarseh, M.I., Sabri, T.G., Al-Momani, I.F.: Chemical Composition of Urban Wet Deposition in Amman, Jordan. Water Air Soil Pollut., 55-65 (1999) https://doi. org/10.1023/A:1005086616451

Kanazu, T., Matsumura, T., Nishiuchi, T., Yamamoto, T.: Effect of simulated acid rain on deterioration of concrete. Acid rain. 2000, 1481-1486 (2001). https://doi.org/10.1007/978-94-007-0810-5_94

Langner, J., H. Rodhe, Crutzen, P. J., Zimmermann, P.: Anthropogenic influence on the distribution of tropospheric sulphate aerosol. Nature, 712-716(1992) https://doi.org/10.1038/359712a0

Masaki, T., Hiroshi, O., Manabu, I.: Controlling Factors of Weak Acid and Base Concentrations in Urban Dewwater, Comparison of Dew Chemistry with Rain and Fog Chemistry. Bull. Chem. Soc. Japan, 757-764 (2002). https://doi.org/10.1246/bcsj.75.757

Massimi, L., Ristorini, M., Eusebio, M., Florendo, D., Adeyemo, A., Brugnoli, D., Canepari, S.: Monitoring and Evaluation of Terni (Central Italy) Air Quality through Spatially Resolved Analyses. Atmosphere, 200 (2017). https://doi.org/10.3390/atmos8100200

Migon, C., Journel, B., Nicolas, E.: Measurement of trace metal wet, dry and total atmospheric fluxes over the Ligurian Sea. Atmospheric Environ., 889-896 (1997) https://doi.org/10.1016/S1352-2310 (96)00242-7

Monika, J., Kulshrestha, U.C., Sarkar, A.K., Parashar, D. C.: Influence of crustal aerosols on wet deposition at urban and rural sites in India. Atmospheric Environ., 5129-5137 (2000). https://doi.org/10.1016/S13522310 (00)00350-2

Orué, M. R., Gaiero, D., Kirschbaum, A: Seasonal characteristics of the chemical composition of rainwaters from Salta city, NW Argentina. Environ. Earth Sci., 16 (2019). https://doi.org/10.1007 /s12665-018-8007-0

Rodhe, H., Langner, J., Gallardo, L., Kjellstrom E.: Global scale transport of acidifying pollutants. Water Air Soil Pollut., 37-50 (1995) https://doi.org/10.1007/BF00483687

Sanusi, A., Wortham, H., Millet, M., Mirabel, P.: Chemical composition of rainwater in eastern France. Atmospheric Environ., 59-71(1996) https://doi.org/10.1016/1352-2310(95)00237-S

Satyanarayana, J., Reddy, L.A.K., Kulshrestha, M.J., Rao, R.N.: Chemical composition of rain water and influence of airmass trajectories at a rural site in an ecological sensitive area of Western Ghats (India). J. Atmospheric Chem., 101 (2010) https://doi.org/10.1007/s10874-011-9193-2

Singh, K. P., Singh, V. K., Malik, A., Sharma, N., Murthy, R.C., Kumar, R.: Hydrochemistry of Wet Atmospheric Precipitation Over an Urban Area in Northern Indo-Gangetic Plains. Environ. Monitor Assess, 237(2007). https://doi.org/10.1007/s10661-006-9472-6

Wu, Y., Xu, Z., Liu, W., Zhao, T., Zhang, X., Jiang, H., Yu, C., Zhou, L., X. Zhou: Chemical compositions of precipitation at three non-urban sites of Hebei Province, North China: Influence of terrestrial sources on ionic composition. Atmospheric Res., 115-123 (2016). https://doi.org/10.1016 /j.atmosres.2016.06.009

Yagasaki, Y., Chishima, T., Okazaki, M., Jeon, D.S., Yoo, J.H., Kim, Y.K.: Acidification of red pine forest soil due to acidic deposition in Chunchon, Korea. Water Air Soil Pollut., 1085-1090 (2001). https://doi. org/10.1023/A:1013942714612

Yun-Ya Y., Gurpal S. T.: Sources and mechanisms of nitrate and orthophosphate transport in urban stormwater runoff from residential catchments. Water Res 112, 176-184 (2017). https://doi.org/10.1016/j. watres.2017.01.039

Publisher's note Springer Nature remains neutral with regard to jurisdictional claims in published maps and institutional affiliations. 


\section{Affiliations}

Luca Ugo Fontanella ${ }^{1}$. Mauro Tomassetti ${ }^{1} \cdot$ Giovanni Visco $^{1} \cdot$ Maria Pia Sammartino $^{1}$

Luca Ugo Fontanella

fontanella_luca@virgilio.com

1 Chemistry Department, Rome University "La Sapienza”, Rome, Italy 